\title{
Ceria-based catalysts for the recovery of elemental sulfur from $\mathrm{SO}_{2}$-laden gas streams
}

\author{
Maria Flytzani-Stephanopoulos*, Tianli Zhu, Yue $\mathrm{Li}^{1}$ \\ Department of Chemical Engineering, Tufts University, Medford, MA 02155, USA
}

\begin{abstract}
The catalytic reduction of $\mathrm{SO}_{2}$ to elemental sulfur by $\mathrm{CO}$ or $\mathrm{CH}_{4}$ over ceria-based catalysts under demanding operating conditions is reported in this paper. $\mathrm{Cu}$ - or $\mathrm{Ni}$-containing ceria catalysts have been shown before to be highly active and selective for $\mathrm{SO}_{2}$ reduction by $\mathrm{CO}$ in dry gas streams or in the presence of low amounts of $\mathrm{H}_{2} \mathrm{O}$. In this work, the activity/selectivity of 10 at.\%La-doped ceria, $\mathrm{Ce}(\mathrm{La}) \mathrm{O}_{x}$, and $\mathrm{Cu}$ - or Ni-containing $\mathrm{Ce}(\mathrm{La}) \mathrm{O}_{x}$ for the $\left(\mathrm{SO}_{2}+\mathrm{CO}\right)$ reaction was tested in gas streams containing $10-45 \mathrm{~mol} \% \mathrm{H}_{2} \mathrm{O}$ at high space velocities $\left(>80,000 \mathrm{~h}^{-1}\right)$. The addition of 5 at. $\%(\sim 2.5 \mathrm{wt}$. $)$ copper or nickel significantly improved the low-temperature $\left(<500^{\circ} \mathrm{C}\right)$ reactivity of $\mathrm{Ce}(\mathrm{La}) \mathrm{O}_{x}$. This was correlated with the improved reducibility of ceria in the metal-ceria catalysts and the ensuing low-temperature activity for the water-gas-shift (WGS) reaction. The combined reduction of $\mathrm{SO}_{2}$ and $\mathrm{NO}$ by $\mathrm{CO}$ was also studied in this work over the same catalysts. In dilute gas mixtures containing 0.1-1.0 $\mathrm{mol}_{\%} \mathrm{SO}_{2}$ and $\mathrm{NO}$, stoichiometric amount of $\mathrm{CO}$ and in the presence of $40 \% \mathrm{H}_{2} \mathrm{O}$, the NO presence in the feed gas enhances both the $\mathrm{SO}_{2}$ conversion and the elemental sulfur yield. At $550^{\circ} \mathrm{C}$, in the presence of $\mathrm{NO}, \mathrm{SO}_{2}$ conversion and sulfur yield over the $5 \% \mathrm{Ni}-\mathrm{Ce}(\mathrm{La}) \mathrm{O}_{x}$ catalyst were 0.94 and 0.77 , respectively, the $\mathrm{NO}$ conversion to $\mathrm{N}_{2}$ was complete, and the $\mathrm{CO}_{2}$ produced was the sum of the $\mathrm{SO}_{2}$ and $\mathrm{NO}$ reduction reactions by $\mathrm{CO}$. Ceria-based materials are also active for $\mathrm{SO}_{2}$ reduction by methane to elemental sulfur at temperatures higher than $550^{\circ} \mathrm{C}$. The addition of $\mathrm{Cu}$ or Ni has a different effect on the sulfur selectivity of ceria under fuel-rich conditions. The $\mathrm{Cu}$-ceria system is a complete oxidation catalyst to a much higher temperature than $\mathrm{Ni}$-ceria. Over $\mathrm{Ni}-\mathrm{CeO}_{2}$, dissociation of methane begins at $<550^{\circ} \mathrm{C}$, and side reactions favor $\mathrm{H}_{2} \mathrm{~S}$ production over elemental sulfur. However, the 5 at. $\% \mathrm{Ni}-\mathrm{Ce}(\mathrm{La}) \mathrm{O}_{x}$ catalyst showed remarkable resistance to carbon deposition, both in the $\mathrm{SO}_{2}$-methane reaction as well as in partial oxidation of methane by $\mathrm{O}_{2}$ to synthesis gas with a $2: 1 \mathrm{H}_{2}: \mathrm{CO}$ ratio. This is attributed to the high dispersion of nickel in this catalyst and the fast rate of oxygen supply from ceria to the nickel interface. Catalysts were characterized by temperature-programmed-reduction, XPS and STEM/EDS. @ 2000 Elsevier Science B.V. All rights reserved.
\end{abstract}

Keywords: Copper oxide; Cerium oxide catalysts; Nickel; Oxygen storage; $\mathrm{SO}_{2}$ reduction; Sulfur recovery; NO reduction; Elemental sulfur; Water-gas-shift; Methane

\section{Introduction}

Sulfur dioxide discharged into the atmosphere, primarily as a product of combustion processes is a

\footnotetext{
* Corresponding author. Tel.: +1-617-627-3048; fax: +1-617-627-3991.

E-mail address: mstephanopoulos@infonet.tufts.edu (M. Flytzani-Stephanopoulos).

${ }^{1}$ Present address: Prototech Co., Needham, MA 02194, USA.
}

major atmospheric pollutant causing various ecological damages and health problems. Flue gas desulfuripzation (FGD) of combustion exhaust gases is presently a costly process often involving complex flowsheets and "throw-away" sorbents [1,2]. Direct catalytic reduction of sulfur dioxide to elemental sulfur by various reductants such as carbon monoxide, methane or synthesis gas is emerging as a promising and cost-effective technological solution for a variety of 
desulfurization problems in chemical, refining, gas processing, metallurgical and power generation industries.

The direct reduction of sulfur dioxide by carbon monoxide to elemental sulfur under dry conditions has been known for a long time [3-5], but no substantial commercial experience exists. The overall reactions involved in this process are as follows:

$\mathrm{SO}_{2}+2 \mathrm{CO} \rightarrow 2 \mathrm{CO}_{2}+(1 / x) \mathrm{S}_{x}$

$\mathrm{CO}+(1 / x) \mathrm{S}_{x} \rightarrow \mathrm{COS}$

$2 \mathrm{COS}+\mathrm{SO}_{2} \rightarrow 2 \mathrm{CO}_{2}+(3 / x) \mathrm{S}_{x}$

where $x=2-8$ or higher. At high temperatures, predominantly gaseous elemental sulfur, $\mathrm{S}_{2}$, is produced through reaction 1 which can further react with $\mathrm{CO}$ to form carbonyl sulfide, COS. This, in turn may again reduce $\mathrm{SO}_{2}$ to elemental sulfur through reaction 3 . However, COS is a more toxic compound than $\mathrm{SO}_{2}$ and its production should be minimized in a sulfur recovery process.

Various active catalyst systems have been reported for the $\mathrm{SO}_{2}$ reduction by $\mathrm{CO}$. Most studied are alumina-supported transition metals and oxides (such as $\mathrm{Cu}, \mathrm{Fe}, \mathrm{Mn}, \mathrm{Cr}, \mathrm{Ni}, \mathrm{Pd}, \mathrm{Ag}$ and others) [6,7]. Production of COS usually proceeds to a substantial extent on these catalysts and water partially poisons the catalyst activity. Lower COS formation was realized on mixed oxides of elements from the lanthanide group and the groups IVA and VA [8] such as La-Ti-O. But this type of catalyst needs to be activated by reducing gases at temperatures above $600^{\circ} \mathrm{C}$ prior to reaction. $\mathrm{ABO}_{3}$ perovskite-type mixed oxides [9-13] were reported to have high selectivity to elemental sulfur over COS. The perovskite structure is lost after a short reaction period, but the resultant mixture of sulfides and oxysulfides remains active [14]. Recently, Ma et al. [15-17] reported on the activity of $\mathrm{La}_{2} \mathrm{O}_{2} \mathrm{~S}$ for this reaction as well as for the combined reduction of $\mathrm{SO}_{2}$ and $\mathrm{NO}$ by $\mathrm{CO}$. High selectivity to elemental sulfur was found in the absence of water. Mixed oxides of $\mathrm{Co}_{3} \mathrm{O}_{4}-\mathrm{TiO}_{2}$ were reported by $\mathrm{Kim}$ et al. [18] to be active and selective catalysts in dry gas streams.

Cerium oxide-based catalysts containing small amounts (1-5wt.\%) of a transition metal oxide such as $\mathrm{Cu}, \mathrm{Ni}$ or $\mathrm{Co}$ appear to be the most active and selective catalysts disclosed to date for the reduction of $\mathrm{SO}_{2}$ by $\mathrm{CO}$, both in dry or wet gas streams [19-24]. This type catalyst has excellent redox activity, produces sulfur as a primary product, can handle even trace amounts of $\mathrm{SO}_{2}$, and can operate at very high space velocities $\left(>80,000 \mathrm{~h}^{-1}\right)$ at temperatures in the range of $400-500^{\circ} \mathrm{C}$. The performance of these catalysts in gases containing excess $\mathrm{H}_{2} \mathrm{O}$ and for the combined reduction of $\mathrm{SO}_{2}$ and $\mathrm{NO}$ is considered in this paper.

The application of ceria-based catalysts to reduction of $\mathrm{SO}_{2}$ by methane is presented in the second part of the paper. Methane is an attractive reductant due to abundant and cheap natural gas. The stoichiometric overall reaction between $\mathrm{SO}_{2}$ and $\mathrm{CH}_{4}$ is

$2 \mathrm{SO}_{2}+\mathrm{CH}_{4} \rightarrow \mathrm{CO}_{2}+2 \mathrm{H}_{2} \mathrm{O}+2[\mathrm{~S}]$

A number of side reactions and intermediate products are, in general, possible in the $\mathrm{SO}_{2}+\mathrm{CH}_{4}$ system. By-products such as $\mathrm{H}_{2} \mathrm{~S}, \mathrm{COS}, \mathrm{CS}_{2}, \mathrm{CO}$ and $\mathrm{H}_{2}$ can be formed under certain conditions. Catalysts previously studied for this reaction include bauxite [25], alumina [26], aluminum-chromium oxides [27], $\mathrm{Fe}-\mathrm{Cu}-\mathrm{Cr}$ and $\mathrm{Cu}-\mathrm{Cr}-\mathrm{Mn}$ oxides [28] and, more recently, transition metal sulfides: $\mathrm{WS}_{2}, \mathrm{FeS}_{2}$ and $\mathrm{MoS}_{2}$ [29-32], and $\mathrm{Co}_{3} \mathrm{O}_{4} / \mathrm{Al}_{2} \mathrm{O}_{3}$ [33]. However, issues of low activity and/or low selectivity to elemental sulfur were reported with all these catalysts. The optimized ratio of $\mathrm{SO}_{2}: \mathrm{CH}_{4}$ used by various authors $[27,28,32]$ is typically lower than the stoichiometric ratio of 2:1 (reaction 4) in order to shift the activity to lower temperature, albeit at the expense of selectivity to elemental sulfur. Additionally, under these fuel-rich conditions, undesired by-products such as $\mathrm{CO}$ as well as elemental carbon may be produced. Sarlis and Berk [26] reported that $\mathrm{CO}$ was formed with the $\mathrm{Al}_{2} \mathrm{O}_{3}$-based catalyst, the rate of $\mathrm{CO}$ formation becoming appreciable at $T>700^{\circ} \mathrm{C}$ and increasing with the $\mathrm{CH}_{4}: \mathrm{SO}_{2}$ ratio. By adding $\mathrm{MoO}_{3}, \mathrm{CO}$ production was suppressed, but elemental carbon was deposited on the catalyst [30]. The rate of carbon formation increased with the $\mathrm{CH}_{4}: \mathrm{SO}_{2}$ ratio, and became comparable to the rate of $\mathrm{CO}_{2}$ production at high temperature.

Cerium oxide is well known for its high oxygen storage capacity and oxygen reducibility which make it a most important additive in the three-way catalyst for a variety of redox reactions in the automotive exhaust gas [34]. Previous work in our lab has shown that ceria-based materials are highly active and stable 
catalysts for $\mathrm{SO}_{2}$ reduction to elemental sulfur by $\mathrm{CO}$ at high space velocity [19-24]. Recently, we have found these catalysts to be very attractive also for the reduction of $\mathrm{SO}_{2}$ by methane [35-37]. The operating temperature is about $200^{\circ} \mathrm{C}$ higher than that for the reduction of $\mathrm{SO}_{2}$ by $\mathrm{CO}$. Under fuel-rich conditions, we have reported a different sulfur selectivity between $\mathrm{Cu}$ - and Ni-containing ceria. This was attributed to the different activity of these two catalysts for side reactions that occur under fuel-rich conditions and in the presence of water vapor. The $\mathrm{Ni}-\mathrm{CeO}_{2}$ system catalyzes the partial oxidation of methane to synthesis gas [38] while the $\mathrm{Cu}-\mathrm{CeO}_{2}$ system remains a complete oxidation catalyst to a much higher temperature than the former. In this paper, these findings are related to the selectivity of each catalyst to elemental sulfur. The stability of $\mathrm{Ni}-\mathrm{CeO}_{2}$ against carbon deposition in $\mathrm{CH}_{4}$-rich conditions is also discussed.

\section{Experimental}

Bulk ceria-based catalysts were prepared by the urea gelation/co-precipitation method using metal nitrates and urea by a procedure described in detail elsewhere [39]. Lanthanum (10 at.\%) was typically used as a dopant of ceria because it suppresses the crystal growth and sintering of ceria during the calcination step $[39,40]$. The doped cerias are denoted as $\mathrm{Ce}(\mathrm{La}) \mathrm{O}_{x}$. Samples were calcined in air for $3 \mathrm{~h}$ at $650^{\circ} \mathrm{C}$ or at $720^{\circ} \mathrm{C}$ for the $\left(\mathrm{SO}_{2}+\mathrm{CO}\right)$ or $\left(\mathrm{SO}_{2}+\mathrm{CH}_{4}\right)$ reaction tests, respectively. The resulting surface area was $90-100 \mathrm{~m}^{2} / \mathrm{g}$ for the $650^{\circ} \mathrm{C}$-calcined samples and $45-70 \mathrm{~m}^{2} / \mathrm{g}$ for the $720^{\circ} \mathrm{C}$ samples, while the bulk density was $1.8-2 \mathrm{~g} / \mathrm{cm}^{3}$.

Bulk elemental analysis was performed by inductively coupled plasma (ICP) atomic emission spectrometry (Perkin-Elmer Plasma 40). The BET surface area was measured in a Micromeritics Pulse ChemiSorb 2705 apparatus. X-ray powder diffraction (XRD) analysis of the samples was performed on a Rigaku 300 instrument. $\mathrm{Cu} \mathrm{K \alpha}$ radiation was used with a power setting of $60 \mathrm{kV}$ and $300 \mathrm{~mA}$. Tungsten was used as the internal d-spacing standard. The catalyst surface composition was determined by X-ray photoelectron spectroscopy (XPS) on a Perkin-Elmer 5100C system. All measurements were carried out at room temperature and without any sample pre-treatment.
A $\mathrm{Mg} \mathrm{K} \alpha \mathrm{X}$-ray source typically set at $15 \mathrm{kV}$ and $20 \mathrm{~mA}$ was used in this work. All binding energies were adjusted relative to $\mathrm{C} 1 \mathrm{~s}$ at $284.6 \mathrm{eV}$. The catalyst microstructure was studied in a vacuum generators HB 603 scanning transmission electron microscope (STEM) equipped with a X-ray microprobe of $0.14 \mathrm{~nm}$ optimum resolution for energy dispersive X-ray spectroscopy (EDS). For STEM analysis, the catalyst powder was dispersed on a nickel or copper grid coated with a carbon film and elemental maps were obtained on a $128 \times 128$ data matrix.

Catalyst activity tests were conducted in a laboratory-scale, packed-bed flow reactor made of quartz (I.D. $=10 \mathrm{~mm}$ ) with a porous quartz frit supporting the catalyst. All samples were in powder form $(<150 \mu \mathrm{m})$. The catalyst loading varied from 150 to $300 \mathrm{mg}$, and the typical flow rate was $100 \mathrm{~cm}^{3} / \mathrm{min}$. The reactor was heated inside a Lindberg electric furnace. The temperature was measured by a quartz tube-sheathed K-type thermocouple placed at the top of the packed bed, and was controlled by a Wizard temperature controller. The reacting gases, all certified calibration gas mixtures with helium (Middlesex), were measured by mass flow controllers and mixed prior to the reactor inlet. The mole percentage of $\mathrm{SO}_{2}$ in the feed gas was typically unity. Water was injected into a heated gas line with a calibrated syringe pump. The experiments were carried out under nearly atmospheric pressure. A cold trap connected at the outlet of the reactor was used to separate and collect the elemental sulfur and water from the product gas stream. The reactants and products were analyzed by an on-line HP5880A gas chromatograph (GC) equipped with a thermal conductivity detector (TCD). A $1 / 8$ in. O.D. $\times 6 \mathrm{ft}$. long Teflon column packed with Porapak QS was employed to separate $\mathrm{CH}_{4}$, $\mathrm{CO}, \mathrm{CO}_{2}, \mathrm{COS}, \mathrm{CS}_{2}, \mathrm{H}_{2} \mathrm{~S}$ and $\mathrm{SO}_{2}$ while a $1 / 4 \mathrm{in}$. O.D. $\times 6 \mathrm{ft}$. long Teflon Chromosil 310 column was used to separate $\mathrm{CO}, \mathrm{CO}_{2}, \mathrm{COS}, \mathrm{CS}_{2}, \mathrm{H}_{2} \mathrm{~S}$ and $\mathrm{SO}_{2}$ in the $\left(\mathrm{SO}_{2}+\mathrm{CO}\right)$ reaction tests. An additional column, Molecular Sieve $5 \mathrm{~A}$, was used to separate $\mathrm{N}_{2}$, $\mathrm{NO}$ and $\mathrm{CO}$ in tests for combined $\mathrm{NO} / \mathrm{SO}_{2}$ reduction.

The results are shown in terms of sulfur dioxide conversion, $\mathrm{X}-\mathrm{SO}_{2}$, and elemental sulfur yield, Y-[S], or selectivity to elemental sulfur $\mathrm{S}$, defined as follows:

$$
\begin{aligned}
& \mathrm{X}-\mathrm{SO}_{2}=\left(\mathrm{SO}_{2_{\text {in }}}-\mathrm{SO}_{2_{\text {out }}}\right) / \mathrm{SO}_{2_{\text {in }}} \\
& \mathrm{Y}-[\mathrm{S}]=\mathrm{S}_{\text {out }} / \mathrm{SO}_{2_{\text {in }}}
\end{aligned}
$$


$\mathrm{S}=\mathrm{Y}-[\mathrm{S}] / \mathrm{X}-\mathrm{SO}_{2}$

where $\mathrm{SO}_{2_{\text {in }}}$ and $\mathrm{SO}_{2_{\text {out }}}$ are mol percentages of $\mathrm{SO}_{2}$ in the feed gas and effluent gas, respectively, while $\mathrm{S}_{\text {out }}$ is the outlet elemental sulfur concentration. Typically, $S_{\text {out }}$ was determined by subtracting the mol percentages of $\mathrm{H}_{2} \mathrm{~S}$ and $\mathrm{COS}$ in the effluent gas from $\mathrm{SO}_{2_{\text {in }}}-\mathrm{SO}_{2_{\text {out }}}$.

Temperature-programmed reduction (TPR) of the as-prepared catalysts $\left(720^{\circ} \mathrm{C}\right.$-calcined) in powder form $(<150 \mu \mathrm{m})$ in a $\mathrm{H}_{2} / \mathrm{He}$ gas mixture was carried out in a Cahn TG 121 thermogravimetric analyzer (TGA). Each sample was preheated to $500^{\circ} \mathrm{C}$ in $\mathrm{He}$ for $30 \mathrm{~min}$ to remove contaminants adsorbed on the sample. After cooling down to room temperature, the samples were heated in a $5 \% \mathrm{H}_{2} / \mathrm{He}$ mixture $\left(600 \mathrm{~cm}^{3} / \mathrm{min}(\mathrm{STP})\right)$ at a heating rate of $10^{\circ} \mathrm{C} / \mathrm{min}$ to $700^{\circ} \mathrm{C}$, while monitoring the catalyst weight change in the TGA.

\section{Results and discussion}

\section{1. $\mathrm{SO}_{2}$ reduction by $\mathrm{CO}$ in the presence of excess water}

Previous studies of the catalytic reduction of $\mathrm{SO}_{2}$ by $\mathrm{CO}$ to elemental sulfur over ceria carried out in our lab [19-22], have shown that oxidizing agents such as carbon dioxide and water vapor inhibit the reaction of $\mathrm{CO}$ with $\mathrm{SO}_{2}$. The activity is restored only at high temperatures upon desorption of water. An earlier FTIR study had shown that adsorption of CO was hindered on a hydroxylated ceria surface [41]. Liu and coworkers [19-21] first showed that incorporation of small amounts of transition metals, such as $\mathrm{Cu}, \mathrm{Ni}, \mathrm{Co}, \mathrm{Pt}$, and others into ceria enhances the catalytic activity of the latter, apparently by providing active surface sites for $\mathrm{CO}$ adsorption. The effect of water vapor content on sulfur yield was reported in an earlier publication on a catalyst with composition 15 at.\% Cu-Ce(4.5 at.\%La)O $\mathrm{O}_{x}$ [19]. The sulfur yield was found to decrease from ca. 0.97 to ca. 0.53 as water vapor was raised from 0 to $4 \mathrm{~mol} \%$. However, further increasing the water vapor content did not cause a change in sulfur yield. Sulfur yield was maintained at the 0.45 level in the presence of 8 or $13 \% \mathrm{H}_{2} \mathrm{O}$ $[19,21]$. Because stoichiometric feed gas $\left(\mathrm{CO}: \mathrm{SO}_{2}=\right.$
2) was used, the produced $\mathrm{H}_{2} \mathrm{~S}$ relative to unreacted $\mathrm{SO}_{2}$ was always kept at the stoichiometric ratio. Both the $\mathrm{SO}_{2}$ conversion and sulfur yield were flat at high temperatures.

$\mathrm{Ni}$ and $\mathrm{Cu}$ are reported to have a similar enhancement effect on the activity of $\mathrm{CeO}_{2}$ catalysts for a reacting gas mixture comprising no water or small amounts of water [19-21]. Higher levels of water vapor were examined recently [24]. Fig. 1 shows sulfur dioxide conversion and sulfur yield over low-content $\mathrm{Cu}-$ or $\mathrm{Ni}-\mathrm{Ce}(\mathrm{La}) \mathrm{O}_{x}$ in the presence of $10 \% \mathrm{H}_{2} \mathrm{O}$. Compared to $\mathrm{Ce}(\mathrm{La}) \mathrm{O}_{x}$, addition of 5 at.\% ( 2.5 wt.\%) copper or nickel significantly improved the low-temperature reactivity of the catalyst and its resistance to water vapor poisoning. Both metal-containing ceria catalysts showed similar performance with respect to $\mathrm{SO}_{2}$ conversion and sulfur yield.

Next, a gas containing a large excess of water $(>40 \%)$ was examined. In practice, this may be the composition of a regenerator offgas stream diluted with large amounts of process steam prior to $\mathrm{SO}_{2}$ reduction. $\mathrm{Ni}-\mathrm{CeO}_{x}$ catalysts were found to retain a much higher activity than $\mathrm{CeO}_{2}$ even in this type of feed gas [24]. Fig. 2 shows that in a reacting gas containing $42.8 \% \mathrm{H}_{2} \mathrm{O}$, the $\mathrm{SO}_{2}$ conversion over the $\mathrm{Ni}-\mathrm{CeO}_{x}$ catalyst is 0.54 at $450^{\circ} \mathrm{C}$ while it is only about 0.15 over the other ceria catalysts at the same temperature. The $\mathrm{Ni}-\mathrm{CeO}_{x}$ catalyst also gives a higher sulfur yield than the other catalysts which correlates with its higher $\mathrm{SO}_{2}$ conversion. Such a large difference is believed to result from available $\mathrm{CO}$ adsorption sites on the metal that are not poisoned by $\mathrm{H}_{2} \mathrm{O}$. Reaction of $\mathrm{CO}$ with $\mathrm{H}_{2} \mathrm{O}$ by the water-gas-shift (WGS) reaction may also assist the main reaction. In Fig. 2, all $\mathrm{CO}$ was consumed at $500^{\circ} \mathrm{C}$ over the Ni-ceria catalyst. As shown first by Liu [21], WGS takes place at a much lower temperature on $\mathrm{Cu} /$ ceria than on ceria. Metal/ceria catalysts may then be used with a variety of $\mathrm{SO}_{2}$-laden gas streams, even when a large excess of process steam is added as a diluent.

Fig. 3 shows the $\mathrm{CO}$ conversion on ceria-based materials used in the WGS reaction. $\mathrm{Cu}$ or $\mathrm{Ni}-\mathrm{Ce}(\mathrm{La}) \mathrm{O}_{x}$ are superior WGS catalysts to $\mathrm{Ce}(\mathrm{La}) \mathrm{O}_{x}$, as indicated by a shift of the reaction light-off temperature to a lower value. This may be attributed to an enhancement of the redox activity of ceria by the presence of the metal $[24,42]$. We have examined this further by 

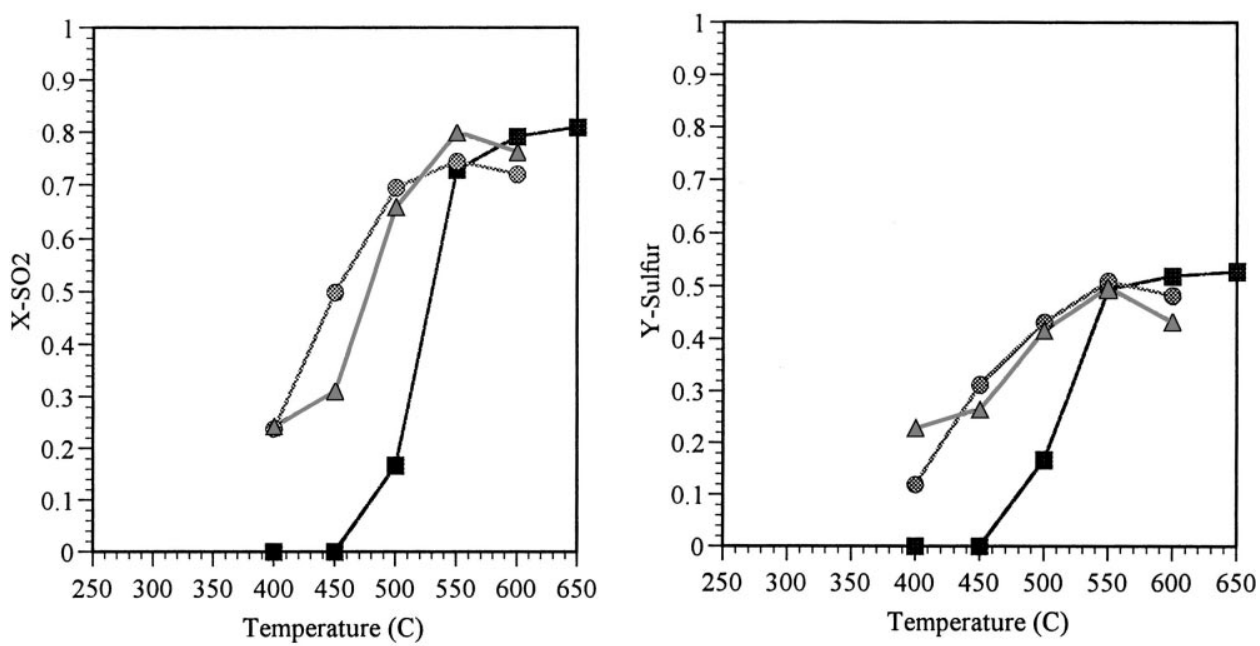

Fig. 1. Effect of metal addition on wet $\mathrm{SO}_{2}$ conversion and sulfur yield over $\mathrm{Ce}(\mathrm{La}) \mathrm{O}_{x}$-based catalysts; all calcined at $650^{\circ} \mathrm{C}$ $\left.\left(1 \% \mathrm{SO}_{2}-2 \% \mathrm{CO}-10.7 \% \mathrm{H}_{2} \mathrm{O}-\mathrm{He}, 0.09 \mathrm{~g} \mathrm{~s} / \mathrm{cm}^{3}(\mathrm{NTP})\right),(\square) \mathrm{Ce}(10 \% \mathrm{La}) \mathrm{O}_{x},(\otimes)\right) 5 \% \mathrm{Cu}-\mathrm{Ce}(\mathrm{La}) \mathrm{O}_{x},(\Delta) 5 \% \mathrm{Ni}-\mathrm{Ce}(\mathrm{La}) \mathrm{O}_{x}$.

comparing the reducibility of metal-modified ceria to that of ceria $[24,39,40,42]$. Similar to what is known for the noble metal/ceria systems [43], the reducibility of $\mathrm{Cu}-$ or $\mathrm{Ni}-\mathrm{CeO}_{2}$ is higher than that of ceria.

Table 1 lists reduction extents of ceria, defined here as the value of $x$ in $\mathrm{Ce}(\mathrm{La}) \mathrm{O}_{x}$ and $\mathrm{Cu}-$ or $\mathrm{Ni}-\mathrm{Ce}(\mathrm{La})-$ $\mathrm{O}_{x}$, obtained from $\mathrm{H}_{2}$-TPR. For example, at $500^{\circ} \mathrm{C}$, $15 \% \mathrm{Cu}-\mathrm{Ce}(\mathrm{La}) \mathrm{O}_{x}$ and $5 \% \mathrm{Ni}-\mathrm{Ce}(\mathrm{La}) \mathrm{O}_{x}$ showed a re-

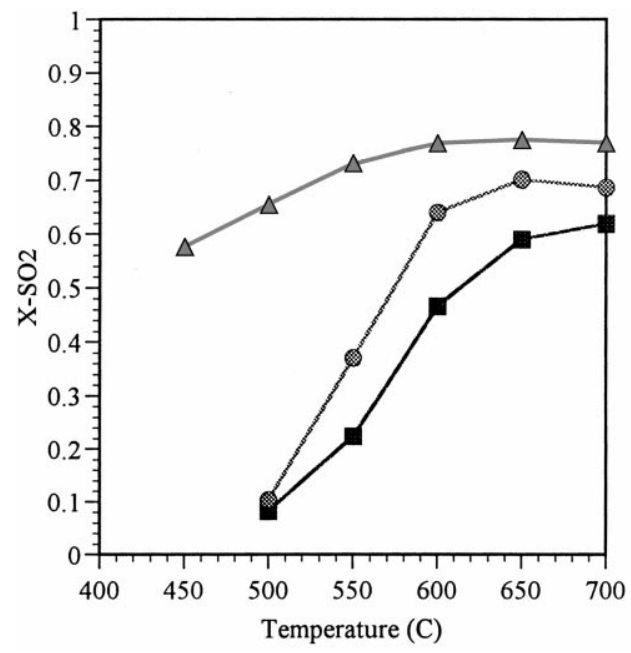

duction extent of 1.80 and 1.84 , respectively, while this was 1.95 for $\mathrm{Ce}(\mathrm{La}) \mathrm{O}_{x}$. Reduction extents of metal-containing ceria are calculated after accounting for complete reduction of the metal oxide to the metal at each temperature. Enhanced reducibility of ceria in the system $\mathrm{Cu}-\mathrm{CeO}_{2}$ was also reported by Rodriguez et al. [44]. Thus, at low temperatures, both the WGS and $\mathrm{SO}_{2}$ reduction reactions are favored on the metal

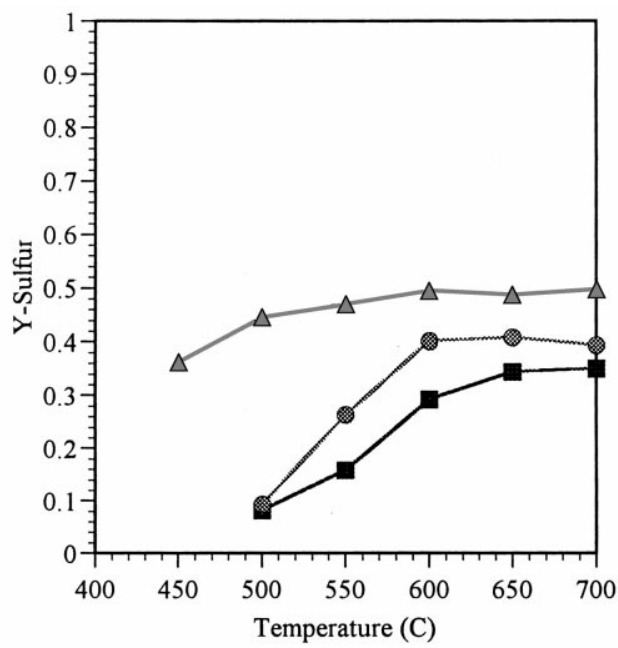

Fig. 2. Effect of catalyst composition with large excess of water vapor in the feed gas $\left(1 \% \mathrm{SO}_{2}-2 \% \mathrm{CO}-42.8 \% \mathrm{H}_{2} \mathrm{O}-\mathrm{He}, 0.09 \mathrm{~g} \mathrm{~s} / \mathrm{cm}^{3}(\mathrm{NTP})\right)$, $\left(\right.$ (口) $\mathrm{CeO}_{2},(\circledast) \mathrm{Ce}(\mathrm{La}) \mathrm{O}_{x},(\Delta) 5 \% \mathrm{Ni}-\mathrm{Ce}(\mathrm{La}) \mathrm{O}_{x}$. 


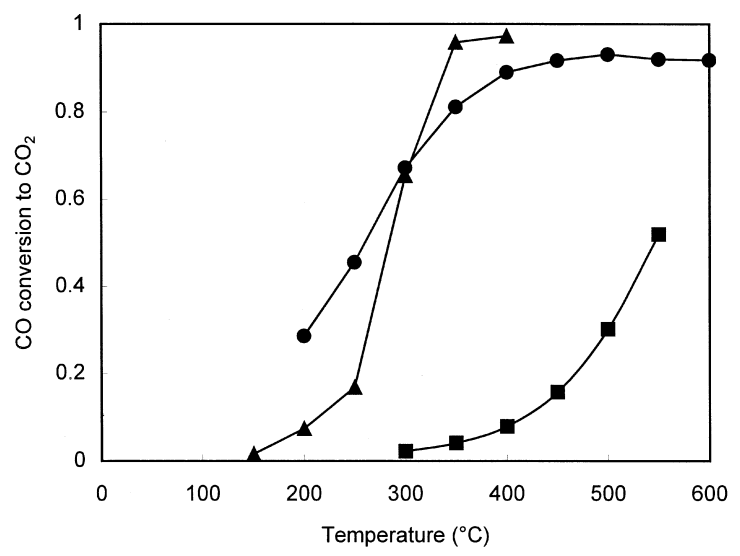

Fig. 3. WGS reaction over ceria-based catalysts (2\%CO-10.7\% $\mathrm{H}_{2} \mathrm{O}-\mathrm{He}, 0.09 \mathrm{~g} \mathrm{~s}^{-\mathrm{cm}^{3}}$ (NTP)), (ロ) $\mathrm{Ce}(10 \% \mathrm{La}) \mathrm{O}_{x}$, (O) $5 \% \mathrm{Cu}-$ $\mathrm{Ce}(\mathrm{La}) \mathrm{O}_{x},(\mathbf{\Delta}) 5 \% \mathrm{Ni}-\mathrm{Ce}(\mathrm{La}) \mathrm{O}_{x}$.

modified ceria, Figs. 1-3, while at high temperatures, the activities of all ceria-based catalysts converge.

\subsubsection{Effect of $\mathrm{NO}$ on the $\mathrm{SO}_{2}$ reduction by $\mathrm{CO}$ : combined $\mathrm{SO}_{2} / \mathrm{NO}_{x}$ reduction}

There is ample scope for studying the simultaneous catalytic reduction of $\mathrm{SO}_{2}$ and $\mathrm{NO}$ in exhaust gas streams, namely for flue gas cleanup application as well as in the automotive exhaust. In connection with the latter, $\mathrm{SO}_{2}$ is detrimental to the three-way catalyst system [45], making it virtually impossible to attain the ultra-low levels of $\mathrm{CO}, \mathrm{NO}$ and hydrocarbon emission specified in current regulations.

The effect of NO on the reduction of sulfur dioxide by carbon monoxide was examined in this work

Table 1

Reduction extents of ceria-based catalysts in $\mathrm{H}_{2}$-TPR

\begin{tabular}{llllllll}
\hline $\begin{array}{l}\text { Catalyst }{ }^{\mathrm{a}} \text { reduction } \\
\text { temperature }\left({ }^{\circ} \mathrm{C}\right)\end{array}$ & 250 & 350 & 400 & 500 & 550 & 600 & 650 \\
\hline $\mathrm{Ce}(10 \% \mathrm{La}) \mathrm{O}_{x}{ }^{\mathrm{b}}$ & 1.99 & 1.99 & 1.98 & 1.95 & 1.91 & 1.87 & 1.84 \\
$15 \% \mathrm{Cu}-\mathrm{Ce}(10 \% \mathrm{La}) \mathrm{O}_{x}{ }^{\mathrm{c}}$ & 1.95 & 1.91 & 1.88 & 1.80 & 1.77 & 1.74 & 1.71 \\
$5 \% \mathrm{Ni}-\mathrm{Ce}(10 \% \mathrm{La}) \mathrm{O}_{x}{ }^{\mathrm{c}}$ & 1.98 & 1.91 & 1.89 & 1.84 & 1.80 & 1.78 & 1.75 \\
\hline
\end{tabular}

${ }^{\text {a }}$ All \% levels are atomic, i.e. $\mathrm{M}$ or $\mathrm{La} /(\mathrm{M}+\mathrm{Ce}+\mathrm{La}) \times 100$; all catalysts calcined at $650^{\circ} \mathrm{C}$.

${ }^{\mathrm{b}}$ Reduction extent expressed as $x$ in $\mathrm{CeO}_{x}$. TPR conditions: $5 \% \mathrm{H}_{2} / \mathrm{He} ; 600 \mathrm{sccm} ; 10^{\circ} \mathrm{C} / \mathrm{min}$ in a TGA.

${ }^{\mathrm{c}}$ Reduction extent expressed as $x$ in $\mathrm{CeO}_{x}$ after subtracting out the oxygen of the MO, i.e. assuming that all $\mathrm{MO}(\mathrm{M}=\mathrm{Cu}$, $\mathrm{Ni})$ was reduced to metal at all temperatures. under wet conditions (with $42.8 \% \mathrm{H}_{2} \mathrm{O}$ ) over the $\mathrm{Ni}-\mathrm{Ce}(\mathrm{La}) \mathrm{O}_{x}$ catalyst. At the same time, the conversion of $\mathrm{NO}$ and $\mathrm{CO}$ was monitored during these tests. Fig. 4a shows steady-state profiles of sulfur dioxide conversion and selectivity to product sulfur versus temperature over the $5 \% \mathrm{Ni}-\mathrm{Ce}(\mathrm{La}) \mathrm{O}_{x}$ catalyst in a feed gas mixture consisting of $1 \% \mathrm{SO}_{2}, 0.5 \% \mathrm{NO}$, $2.7 \% \mathrm{CO}, 42.8 \% \mathrm{H}_{2} \mathrm{O}$, bal. $\mathrm{He}$ at a contact time of $0.09 \mathrm{~g} \mathrm{~s} / \mathrm{cc}(\mathrm{NTP})$. Results for the reacting gas mixture free of NO are included for comparison. For $\mathrm{SO}_{2}$, reduction by $\mathrm{CO}$ to elemental sulfur, addition of NO significantly promotes both the $\mathrm{SO}_{2}$ conversion and selectivity to sulfur. At $550^{\circ} \mathrm{C}$, in the presence of $0.5 \% \mathrm{NO}, \mathrm{SO}_{2}$ conversion and selectivity to sulfur are 0.94 and 0.82 , respectively, which corresponds to a sulfur yield of 0.77 . This is a very impressive value, considering the high content of water present. More interestingly, as shown in Fig. 4b, the NO conversion to $\mathrm{N}_{2}$ is $100 \%$ at temperatures above $500^{\circ} \mathrm{C}$. Due to higher conversion of $\mathrm{SO}_{2}$ in the presence of $\mathrm{NO}$, the measured $\mathrm{CO}_{2}$ yield is higher.

In the presence of $\mathrm{H}_{2} \mathrm{O}$ and $\mathrm{NO}$, various side reactions may take place in the $\mathrm{SO}_{2}+\mathrm{CO}$ reaction system. Some of these are as follows:

$$
\begin{aligned}
& \mathrm{CO}+\mathrm{H}_{2} \mathrm{O} \rightarrow \mathrm{CO}_{2}+\mathrm{H}_{2} \\
& \mathrm{H}_{2}+[\mathrm{S}] \rightarrow \mathrm{H}_{2} \mathrm{~S} \\
& 2 \mathrm{CO}+2 \mathrm{NO} \rightarrow 2 \mathrm{CO}_{2}+\mathrm{N}_{2} \\
& \mathrm{CO}+2 \mathrm{NO} \rightarrow \mathrm{N}_{2} \mathrm{O}+\mathrm{CO}_{2} \\
& 2 \mathrm{H}_{2}+2 \mathrm{NO} \rightarrow \mathrm{N}_{2}+2 \mathrm{H}_{2} \mathrm{O} \\
& \mathrm{H}_{2}+2 \mathrm{NO} \rightarrow \mathrm{N}_{2} \mathrm{O}+\mathrm{H}_{2} \mathrm{O}
\end{aligned}
$$

In addition, $\mathrm{CeO}_{2}$-based systems catalyze the reverse Claus reaction, and the hydrolysis of COS to $\mathrm{H}_{2} \mathrm{~S}$ which is complete above $200^{\circ} \mathrm{C}$ [21].

Table 2 shows the experimental data collected at the conditions of Fig. 4 over 5 at.\% Ni-Ce(La)O $\mathrm{O}_{x}$ [24]. As can be seen from the value of $\Delta \mathrm{Y}-\mathrm{CO}_{2}$, the WGS reaction (5) which is responsible (along with reaction 6) for the reduced $\mathrm{SO}_{2}$ conversion and sulfur yield under wet conditions (Fig. 2), seems to be suppressed in the presence of $0.5 \% \mathrm{NO}$ in the gas stream. Alternatively, the data in Table 2 may be interpreted as the combination of the WGS and reaction 9, the latter consuming any hydrogen produced by WGS to react with NO 
(a)
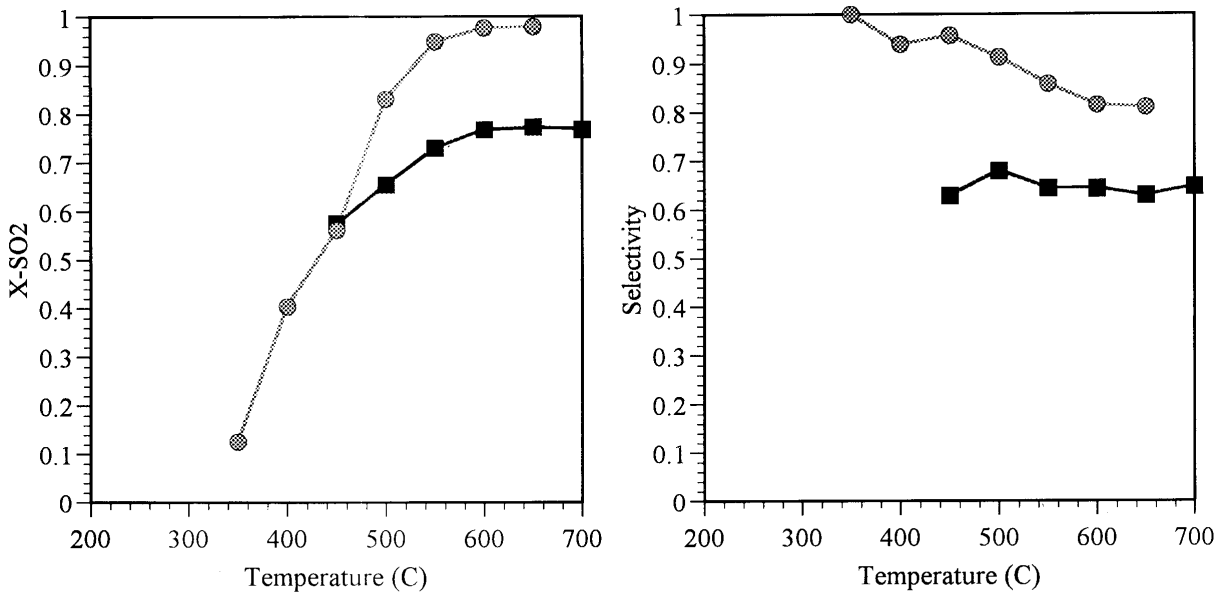

(b)
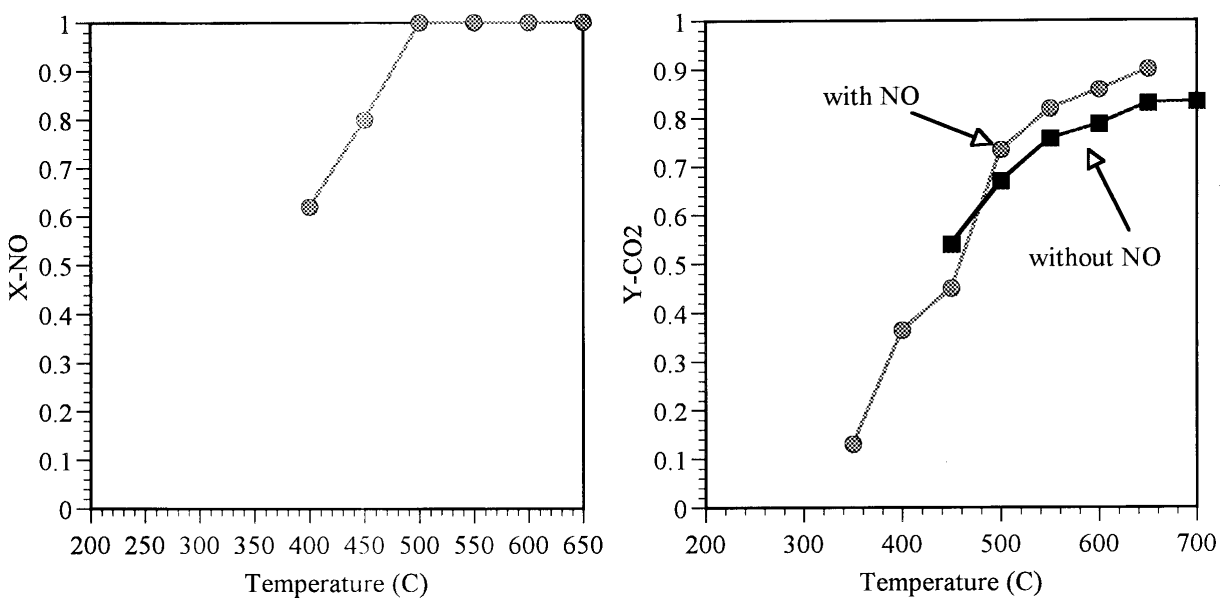

Fig. 4. Combined $\mathrm{SO}_{2} / \mathrm{NO}$ reduction by $\mathrm{CO}$ in excess $\mathrm{H}_{2} \mathrm{O}$-containing stream over $5 \% \mathrm{Ni}-\mathrm{Ce}(\mathrm{La}) \mathrm{O}_{x}$ (a) $\mathrm{SO} 2$ conversion and sulfur

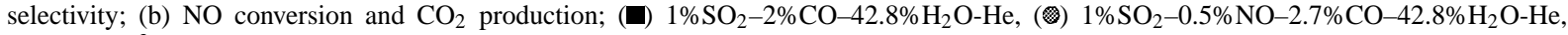
$\left(0.09 \mathrm{~g} \mathrm{~s}^{-\mathrm{cm}^{3}}\right.$ (NTP)).

rather than sulfur by reaction 6 . In either case, the selectivity to elemental sulfur would be higher. The data shown in Table 2 are for a concentration of CO slightly above the stoichiometric corresponding to reactions 1 and 7. When excess $\mathrm{CO}$ was used in the feed gas, the conversion of $\mathrm{SO}_{2}$ approached $100 \%$ at $550^{\circ} \mathrm{C}$, but at a loss of sulfur selectivity [24].

On the basis of Fig. 4 and Table 2, Ni-CeO 2 appears to be a very effective catalyst for the simultaneous reduction of $\mathrm{SO}_{2}$ and $\mathrm{NO}$ by $\mathrm{CO}$ to elemental sulfur and $\mathrm{N}_{2}$, respectively. This catalyst was further investigated with a gas mixture comprising very low concentrations of reactants [24], the results being consistent with the above findings. The simultaneous reduction of $\mathrm{SO}_{2}$ and $\mathrm{NO}$ by $\mathrm{CO}$ was also investigated recently by $\mathrm{Ma}$ et al. [15-17] over $\mathrm{La}_{2} \mathrm{O}_{2} \mathrm{~S}$. Higher than $97 \% \mathrm{SO}_{2}$ and $\mathrm{NO}$ conversions were obtained over the temperature range from 450 to $600^{\circ} \mathrm{C}$. Sulfur yield was above $93 \%$. But, no information about the water effect under these conditions was reported. In sum- 
Table 2

Combined $\mathrm{SO}_{2} / \mathrm{NO}$ reduction over $5 \% \mathrm{Ni}-\mathrm{Ce}(\mathrm{La}) \mathrm{O}_{x}{ }^{\mathrm{a}}$

\begin{tabular}{|c|c|c|c|c|c|}
\hline Temperature $\left({ }^{\circ} \mathrm{C}\right)$ & $\mathrm{X}-\mathrm{SO}_{2}{ }^{\mathrm{b}}$ & $\mathrm{X}-\mathrm{NO}^{\mathrm{c}}$ & $\mathrm{Y}-\mathrm{CO}_{2}{ }^{\mathrm{d}}(\%)$ & $\mathrm{Y}-\mathrm{CO}_{2}{ }^{\mathrm{e}}(\%)$ & $\Delta \mathrm{Y}-\mathrm{CO}_{2}{ }^{\mathrm{f}}(\%)$ \\
\hline 400 & 0.404 & 0.62 & 1.672 & 1.677 & - \\
\hline 450 & 0.561 & 0.8 & 2.290 & 2.294 & - \\
\hline 500 & 0.831 & 1.0 & 3.378 & 3.375 & - \\
\hline 550 & 0.949 & 1.0 & 3.737 & 3.76 & - \\
\hline 600 & 0.977 & 1.0 & 3.823 & 3.94 & 0.117 \\
\hline 650 & 0.979 & 1.0 & 3.827 & 4.13 & 0.303 \\
\hline
\end{tabular}

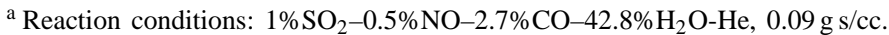

${ }^{\mathrm{b}}$ Conversion of $\mathrm{SO}_{2}$, measured.

${ }^{\mathrm{c}}$ Conversion of NO, measured.

${ }^{d}$ Yield of $\mathrm{CO}_{2}$, calculated from the stoichiometric ratio of $\mathrm{CO}: \mathrm{SO}_{2}=2: 1$ and $\mathrm{CO}: \mathrm{NO}=1: 1$ in reactions 1 and 7 .

e Yield of $\mathrm{CO}_{2}$, measured.

${ }^{\mathrm{f}}$ Difference of $\mathrm{d}-\mathrm{c}$ is $\mathrm{Y}-\mathrm{CO}_{2}$ from water-gas-shift, reaction 5.

mary, $\mathrm{Ni}-\mathrm{CeO}_{x}$ appears to be the most active catalyst for reduction of both $\mathrm{SO}_{2}$ and $\mathrm{NO}$ by $\mathrm{CO}$. This is a very useful result for $\mathrm{NO}_{x}$ reduction because most $\mathrm{NO}$ reduction catalysts are susceptible to sulfur poisoning.

It has been reported that reduced ceria is a good $\mathrm{H}_{2} \mathrm{~S}$ sorbent [46]. A separate experiment was conducted here to confirm that the product of the $\mathrm{SO}_{2}$ reduction was indeed elemental sulfur and not $\mathrm{H}_{2} \mathrm{~S}$ absorbed by the bulk oxide. In this experiment, the reaction was carried out over $5 \% \mathrm{Ni}-\mathrm{Ce}(\mathrm{La}) \mathrm{O}_{x}$ at $600^{\circ} \mathrm{C}$ for $6 \mathrm{~h}$, monitoring the amount of $\mathrm{H}_{2} \mathrm{~S}$. The feed gas contained $1 \% \mathrm{SO}_{2}, 0.5 \% \mathrm{NO}, 2.5 \% \mathrm{CO}, 42.8 \% \mathrm{H}_{2} \mathrm{O}$, bal. $\mathrm{He}$, and a flowrate of $100 \mathrm{sccm}$ was used. The catalyst load was $150 \mathrm{mg}$. Under the assumption that all available $\mathrm{CeO}_{2}$ was fully sulfided to $\mathrm{CeS}_{2}$, it would take $1.86 \mathrm{~h}$ to complete the sulfidation. Thus, under ideal absorption conditions where no diffusion limitations are present and for the above (high) sulfur capture by ceria ( $2 \mathrm{~S} / \mathrm{Ce})$, $\mathrm{H}_{2} \mathrm{~S}$ breakthrough would occur after $\sim 2 \mathrm{~h}$. However, as shown in Fig. 5, the yield of $\mathrm{H}_{2} \mathrm{~S}$ was constant at $\sim 14 \%$ over the $6 \mathrm{~h}$-long test while $\mathrm{X}-\mathrm{SO}_{2}$ was $94 \%$. This proves that the main reaction product was indeed elemental sulfur under these conditions. Additionally, this figure demonstrates the good activity/selectivity and stability of the $5 \% \mathrm{Ni}-\mathrm{Ce}(\mathrm{La}) \mathrm{O}_{x}$ catalyst in this reaction system.

\section{2. $\mathrm{SO}_{2}$ reduction by $\mathrm{CH}_{4}$}

\subsubsection{Catalyst activity and selectivity}

Ceria-based materials are also active catalysts for $\mathrm{SO}_{2}$ reduction to elemental sulfur by methane [35-37].
However, due to the refractory nature of methane, the reaction light-off temperature is about $600^{\circ} \mathrm{C}$ with a stoichiometric feed gas composition, i.e. $\sim 200^{\circ} \mathrm{C}$ higher than that of $\mathrm{SO}_{2}$ reduction by $\mathrm{CO}$ over the same materials. The $\mathrm{CH}_{4}: \mathrm{SO}_{2}$ feed ratio $R$, had a significant effect on the $\mathrm{SO}_{2}$ conversion and sulfur selectivity. Fig. 6 shows the $\mathrm{SO}_{2}$ conversion and sulfur selectivity profiles versus temperature for $5 \% \mathrm{Cu}-\mathrm{Ce}(\mathrm{La}) \mathrm{O}_{x}$ at different $R$. The higher the ratio, the higher the $\mathrm{SO}_{2}$ conversion and the lower the catalyst selectivity to elemental sulfur, even though no drop of selectivity was

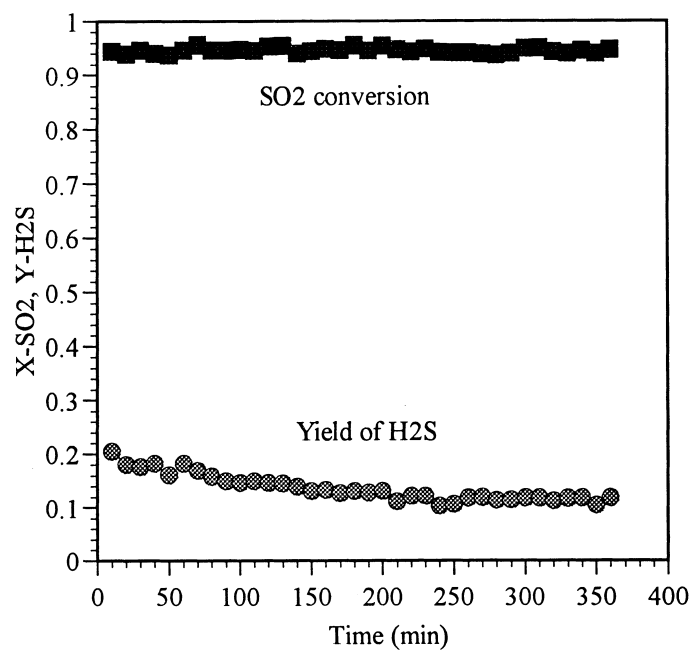

Fig. 5. Long-term stability of $5 \% \mathrm{Ni}-\mathrm{Ce}(\mathrm{La}) \mathrm{O}_{x}$ catalyst; $1 \% \mathrm{SO}_{2}-0.5 \% \mathrm{NO}-2.5 \% \mathrm{CO}-42.8 \% \mathrm{H}_{2} \mathrm{O}-\mathrm{He} \quad\left(600^{\circ} \mathrm{C}, 0.09 \mathrm{~g} \mathrm{~s} / \mathrm{cm}^{3}\right.$ (NTP)). 

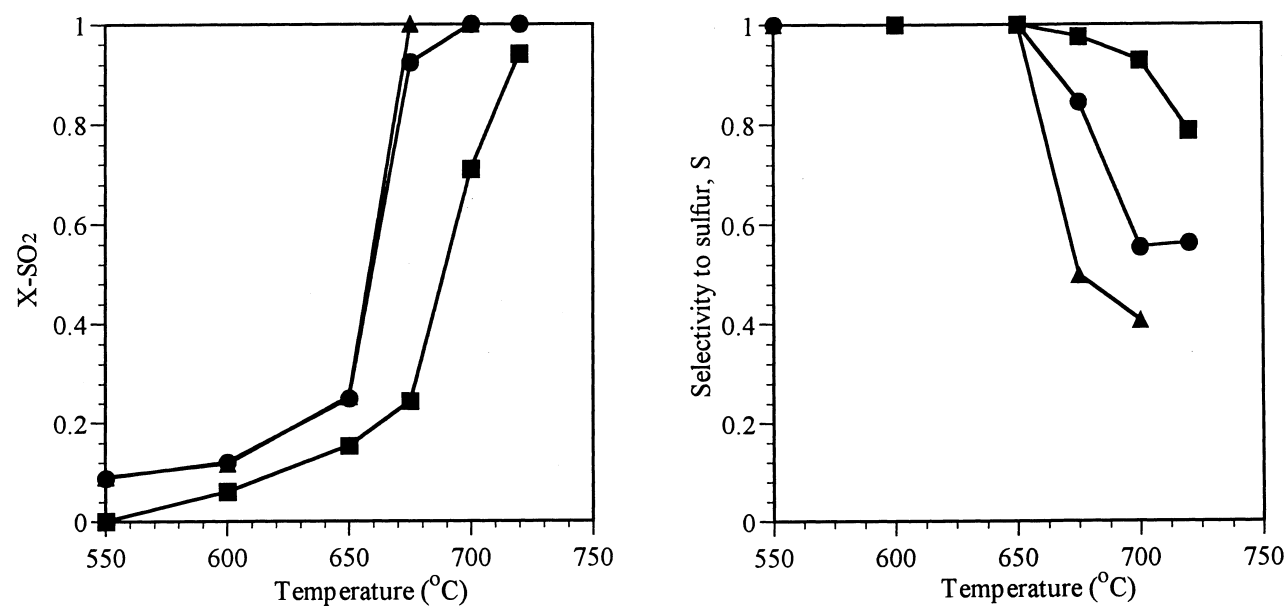

Fig. 6. Effect of the $\mathrm{CH}_{4}: \mathrm{SO}_{2}$ feed ratio, $R$, on the light-off and sulfur selectivity of the $\mathrm{SO}_{2}$ reduction by $\mathrm{CH}_{4}$ over the $5 \% \mathrm{Cu}-\mathrm{Ce}(\mathrm{La}) \mathrm{O}_{x}$

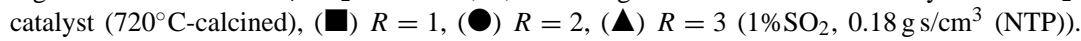

observed below $650^{\circ} \mathrm{C}$. By using excess methane, we can lower the reaction temperature, keeping both high $\mathrm{SO}_{2}$ conversion and sulfur yield at an optimized level. Complete conversion of $\mathrm{SO}_{2}$ and $83 \%$ sulfur yield were obtained at $675^{\circ} \mathrm{C}$ over a $5 \% \mathrm{Cu}-\mathrm{Ce}(\mathrm{La}) \mathrm{O}_{x}$ catalyst at a feed ratio of $\mathrm{CH}_{4}: \mathrm{SO}_{2}=2$ which is four times the stoichiometric ratio for reaction 4 . However, undesirable $\mathrm{CO}$ as well as $\mathrm{H}_{2} \mathrm{~S}$ were detected in the product gases at temperatures above $650^{\circ} \mathrm{C}$ when the value of $R$ exceeded unity.

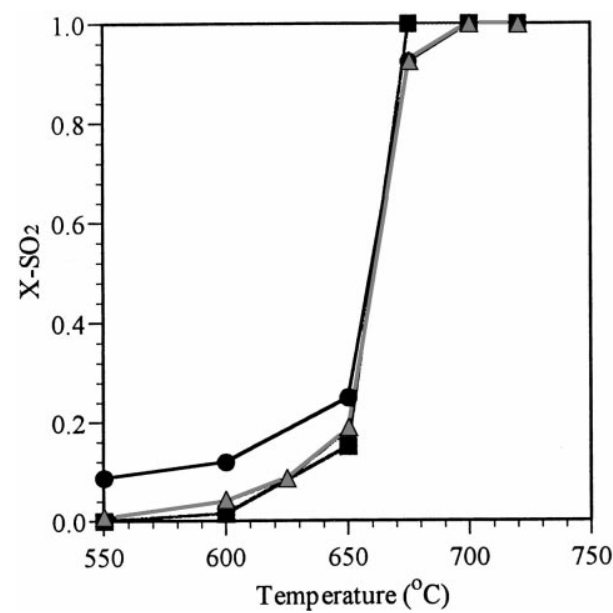

The addition of 5 at. $\% \mathrm{Ni}$ or $\mathrm{Cu}$ had a negligible effect on the activity of $\mathrm{Ce}(\mathrm{La}) \mathrm{O}_{x}$ as shown in Fig. 7, and reported elsewhere [35-37]. This is contrasted with the reduction of $\mathrm{SO}_{2}$ by $\mathrm{CO}$ where addition of the same amount of these metals in $\mathrm{Ce}(\mathrm{La}) \mathrm{O}_{x}$ has a measurable effect [19-24,35]. This is because the light-off temperature of ceria-based materials for the $\mathrm{SO}_{2}+\mathrm{CH}_{4}$ reaction depends on the thermal stability of surface sulfates whose decomposition temperature is $\sim 550^{\circ} \mathrm{C}[23,35,36]$. Cu-modified $\mathrm{Ce}(\mathrm{La}) \mathrm{O}_{x}$

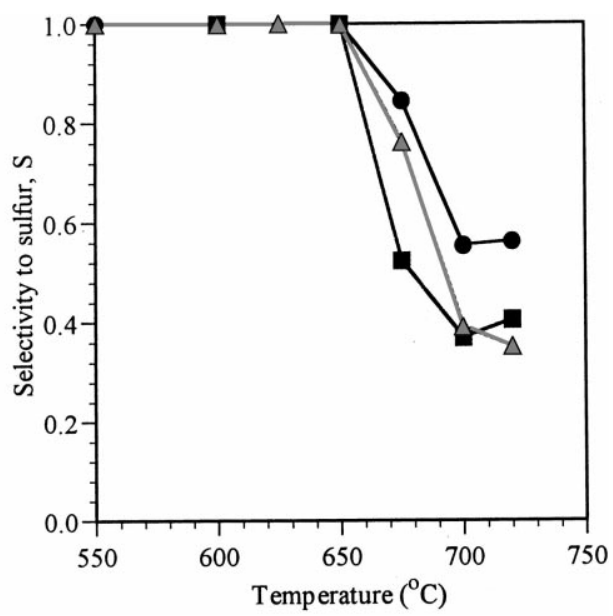

Fig. 7. Effect of catalyst composition on the light-off and sulfur selectivity of the $\mathrm{SO}_{2}$ reduction by $\mathrm{CH}_{4}$ over ceria-based catalysts $\left(720^{\circ} \mathrm{C}\right.$-calcined) $\left(1 \% \mathrm{SO}_{2}-2 \% \mathrm{CH}_{4}-\mathrm{He}, 0.18 \mathrm{~g} \mathrm{~s} / \mathrm{cm}^{3}\right.$ (NTP)), (ロ) $\mathrm{Ce}(\mathrm{La}) \mathrm{O}_{x},(\mathbf{O}) 5 \% \mathrm{Cu}-\mathrm{Ce}(\mathrm{La}) \mathrm{O}_{x},(\Delta) 5 \% \mathrm{Ni}-\mathrm{Ce}(\mathrm{La}) \mathrm{O}_{x}$. 


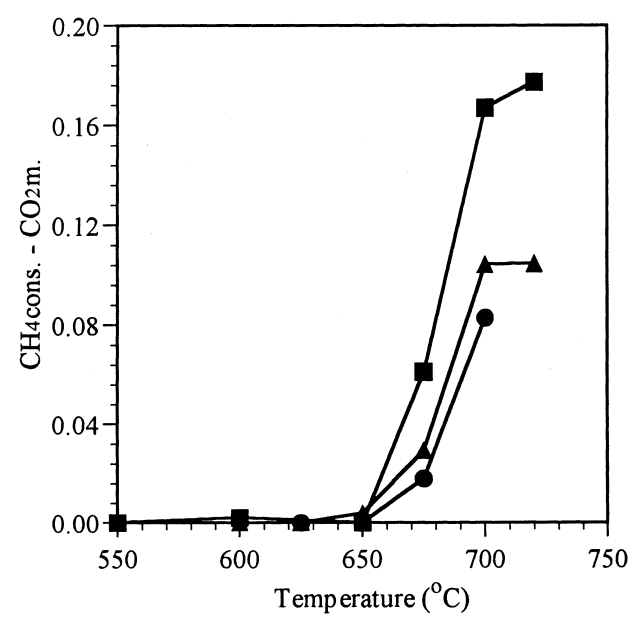

Fig. 8. Effect of catalyst composition on the difference between methane consumption and $\mathrm{CO}_{2}$ production in $1 \% \mathrm{SO}_{2}-2 \% \mathrm{CH}_{4}-\mathrm{He}$,

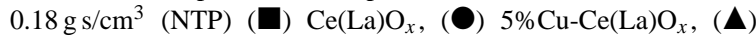
$5 \% \mathrm{Ni}-\mathrm{Ce}(\mathrm{La}) \mathrm{O}_{x}$.

showed the highest selectivity to elemental sulfur under fuel-rich conditions as shown in Fig. 7. On the other hand, the selectivity of nickel-modified $\mathrm{Ce}(\mathrm{La}) \mathrm{O}_{x}$ was a complex function of feed ratio and temperature, as will be discussed below.

Under fuel-rich conditions $(R>0.5)$, the measured $\mathrm{CO}_{2}$ product accounts for most of the $\mathrm{CH}_{4}$ consumption while $\mathrm{CO}$ was also detected in the product gases. Fig. 8 shows the difference between the $\mathrm{CH}_{4}$ consumed and $\mathrm{CO}_{2}$ measured in the exit gas as a function of temperature for the three catalyst compositions under the conditions of Fig. 7. The measured amount of $\mathrm{CO}$ produced was close to the difference between the measured $\mathrm{CH}_{4}$ consumption and $\mathrm{CO}_{2}$ production. The carbon balance was better than $95 \%$. Although we did not directly measure carbon formation, these results indicate that there was no or negligible carbon formation on the catalysts even under fuel-rich conditions. This was confirmed by XPS and other analysis of used samples [47].

Nekrich et al. [28] have proposed the following two parallel overall reactions for the $\mathrm{SO}_{2}+\mathrm{CH}_{4}$ system:

$$
\begin{aligned}
& \mathrm{CH}_{4}+2 \mathrm{SO}_{2}=2[\mathrm{~S}]+\mathrm{CO}_{2}+2 \mathrm{H}_{2} \mathrm{O} \\
& \mathrm{CH}_{4}+\mathrm{SO}_{2}=\mathrm{H}_{2} \mathrm{~S}+\mathrm{CO}+\mathrm{H}_{2} \mathrm{O}
\end{aligned}
$$

The formation of $\mathrm{CO}$ and $\mathrm{H}_{2} \mathrm{~S}$ under fuel-rich conditions suggests that reaction 11 also occurs on ceriabased catalysts. Thus, methane is consumed both by complete oxidation by $\mathrm{SO}_{2}$ to $\mathrm{CO}_{2}$ and $\mathrm{H}_{2} \mathrm{O}$, and by partial oxidation to $\mathrm{CO}$ and $\mathrm{H}_{2}$ products. The $\mathrm{H}_{2}$ produced would further react with surface sulfur to form $\mathrm{H}_{2} \mathrm{~S}$, resulting in low sulfur yield at temperatures higher than $650^{\circ} \mathrm{C}$ (Fig. 7).

Ceria-based materials such as $\mathrm{Cu}-\mathrm{CeO}_{2}$ and $\mathrm{Ni}-\mathrm{CeO}_{2}$ are active for total oxidation of methane at temperatures in the range $350-550^{\circ} \mathrm{C}[21,39,48,49]$. Recently, Otsuka et al. [50-52] showed that ceria can also directly convert methane to syngas with $\mathrm{H}_{2}: \mathrm{CO}=2$ at temperatures higher than $600^{\circ} \mathrm{C}$. In this work, we examined the activity of $\mathrm{Ce}(\mathrm{La}) \mathrm{O}_{x}$ in fuelrich methane oxidation with a $\mathrm{CH}_{4}: \mathrm{O}_{2}$ molar feed ratio of 2 in the absence of $\mathrm{SO}_{2}$. In agreement with Otsuka et al. [50-52], partial oxidation products, i.e. $\mathrm{CO}$ and $\mathrm{H}_{2}$, were observed on $\mathrm{Ce}(\mathrm{La}) \mathrm{O}_{x}$ at temperatures higher than $650^{\circ} \mathrm{C}$ as shown in Fig. 9 . However, the activity and selectivity of $\mathrm{Ce}(\mathrm{La}) \mathrm{O}_{x}$ for partial oxidation of methane (POM) were very low. Addition of 5 at $\% \mathrm{Ni}$ into $\mathrm{Ce}(\mathrm{La}) \mathrm{O}_{x}$ caused a dramatic improvement in POM activity (Fig. 9). Oxygen was completely converted at all temperatures tested. The POM light-off temperature is $550^{\circ} \mathrm{C}$ while only complete oxidation products $-\mathrm{CO}_{2}$ and $\mathrm{H}_{2} \mathrm{O}$, were formed at $T<550^{\circ} \mathrm{C}$. Methane conversion increased with temperature. At $650^{\circ} \mathrm{C}, \sim 94 \%$ methane conversion was measured and the $\mathrm{CO}$ yield was $82 \%$, close to the equilibrium value [53] as shown in Fig. 9. The carbon balance was better than $95 \%$. On the other hand, addition of $\mathrm{Cu}$ into $\mathrm{Ce}(\mathrm{La}) \mathrm{O}_{x}$ suppressed the partial oxidation of methane up to $730^{\circ} \mathrm{C}$ as can be seen in Fig. 9.

The above results confirm that partial oxidation of methane can take place on ceria-based materials to produce synthesis gas, $\mathrm{CO}$ and $\mathrm{H}_{2}$. While 5 at. $\% \mathrm{Ni}$ $\mathrm{Ce}(\mathrm{La}) \mathrm{O}_{x}$ is much more active for POM than $\mathrm{Ce}(\mathrm{La})-$ $\mathrm{O}_{x}$, the addition of $\mathrm{Cu}$ into $\mathrm{Ce}(\mathrm{La}) \mathrm{O}_{x}$ suppresses the partial oxidation of methane. Thus, $\mathrm{Cu}-\mathrm{Ce}(\mathrm{La}) \mathrm{O}_{x}$ continues to be a complete oxidation catalyst to a much higher temperature $\left(730^{\circ} \mathrm{C}\right)$ than $\mathrm{Ni}-\mathrm{Ce}(\mathrm{La}) \mathrm{O}_{x}$. These findings indicate that in the $\mathrm{SO}_{2}+\mathrm{CH}_{4}$ reaction system, $\mathrm{SO}_{2}$ acts as the oxygen source instead of $\mathrm{O}_{2}$, except that the catalyst surface may be partially sulfated during the reaction [37]. Therefore, addition of copper catalyzes reaction 4 rather than reaction 11 which improves sulfur yield. On the other hand, $\mathrm{Ni}-\mathrm{Ce}(\mathrm{La}) \mathrm{O}_{x}$ materials appear to be more active for reaction 11 than $\mathrm{Ce}(\mathrm{La}) \mathrm{O}_{x}$. 

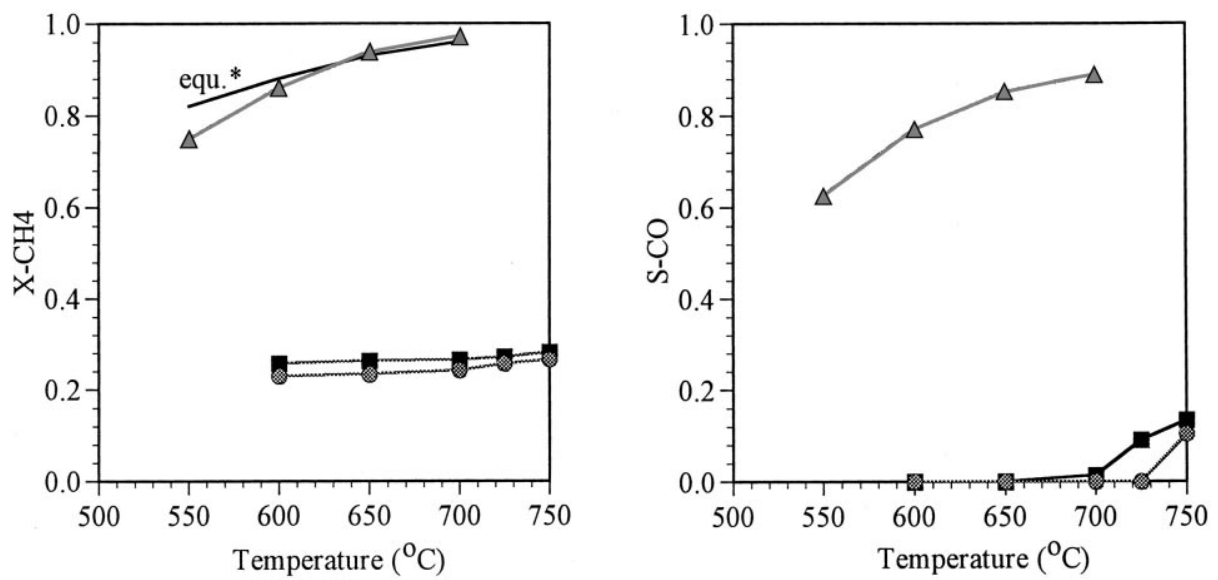

Fig. 9. Partial oxidation of methane over $(\square) \mathrm{Ce}(\mathrm{La}) \mathrm{O}_{x}$, (®) $5 \% \mathrm{Cu}-\mathrm{Ce}(\mathrm{La}) \mathrm{O}_{x},(\Delta) 5 \% \mathrm{Ni}-\mathrm{Ce}(\mathrm{La}) \mathrm{O}_{x}$ catalysts $\left(650^{\circ} \mathrm{C}-\right.$ calcined $)$ $\left(3 \% \mathrm{CH}_{4}-1.5 \% \mathrm{O}_{2}-\mathrm{He}, 0.36 \mathrm{~g} \mathrm{~s} / \mathrm{cm}^{3}(\mathrm{NTP})\right) ; \mathrm{X}_{-}-\mathrm{CH}_{4}=$ methane conversion, $\mathrm{S}-\mathrm{CO}=$ selectivity to $\mathrm{CO}=$ yield of $\mathrm{CO} / \mathrm{X}-\mathrm{CH}_{4}$.

Under methane-rich conditions, carbon formation is a potential problem which will deactivate the catalysts. Claridge et al. [54] observed that $\mathrm{Ni}$ had the highest rate of coke formation compared to other metals (Pd, Rh, Ru, Pt, Ir). Rapid carbon deposition on supported Ni catalysts has been a major consideration in studies of the POM reaction. However, the results of the present study suggest that carbon formation on $\mathrm{Ce}(\mathrm{La}) \mathrm{O}_{x}, 5$ at. $\% \mathrm{Cu}-\mathrm{Ce}(\mathrm{La}) \mathrm{O}_{x}$ and 5 at. $\% \mathrm{Ni}-\mathrm{Ce}(\mathrm{La}) \mathrm{O}_{x}$ catalysts was negligible under fuel-rich conditions. Since Ni-containing ceria may be more prone to coke formation, the 5 at. $\% \mathrm{Ni}-\mathrm{Ce}(\mathrm{La}) \mathrm{O}_{x}$ material was further tested in $\mathrm{POM}$ at $650^{\circ} \mathrm{C}$ for $100 \mathrm{~h}$ with a $\mathrm{CH}_{4}: \mathrm{O}_{2}$ feed ratio of 2 at a contact time of $0.18 \mathrm{~g} \mathrm{~s} / \mathrm{cc}$. No deactivation was observed during $100 \mathrm{~h}$-on-stream as shown in Fig. 10. Methane conversion and $\mathrm{CO}$ yield were maintained at $\sim 90 \%$ and $82 \%$, respectively. This catalyst was characterized further as described below.

\subsubsection{Catalyst characterization}

XPS was used to analyze the surface composition of $5 \% \mathrm{Ni}-\mathrm{Ce}(\mathrm{La}) \mathrm{O}_{x}$ samples after use in $\mathrm{SO}_{2}+\mathrm{CH}_{4}$ reaction with a feed ratio $\mathrm{CH}_{4}: \mathrm{SO}_{2}=2$ or after $100 \mathrm{~h}$ on-stream at $650^{\circ} \mathrm{C}$ in $\mathrm{POM}\left(\mathrm{CH}_{4}: \mathrm{O}_{2}=2\right)$. Fig. 11 shows the $\mathrm{O} 1 \mathrm{~s}$ and $\mathrm{C} 1 \mathrm{~s}$ spectra of these samples and as-prepared $5 \% \mathrm{Ni}-\mathrm{CeO}_{2}$ for comparison. Two $\mathrm{O} 1 \mathrm{~s}$ peaks were found in the XP spectra of the used catalysts. The high binding energy peak at $\sim 531.8 \mathrm{eV}$ can be assigned to sulfate or carbonate while the low bind- ing energy peak at $\sim 529.4 \mathrm{eV}$ is assigned to metal oxide [55]. The C1s spectra show a prominent peak at a binding energy of $284.6 \mathrm{eV}$ which is assigned to residual hydrocarbons. A small peak at $288.5 \mathrm{eV}$ which was also observed on the fresh materials, may be due to residual surface $\mathrm{CO}_{3}{ }^{2-}$. There was no peak due to graphitic or carbidic surface carbon species whose binding energy is at $\sim 283 \mathrm{eV}$ [55]. The deconvolution of the $\mathrm{C} 1 \mathrm{~s}$ signal of used $5 \% \mathrm{Ni}-\mathrm{Ce}(\mathrm{La}) \mathrm{O}_{x}$ catalysts gave a dominant peak of full width at half height

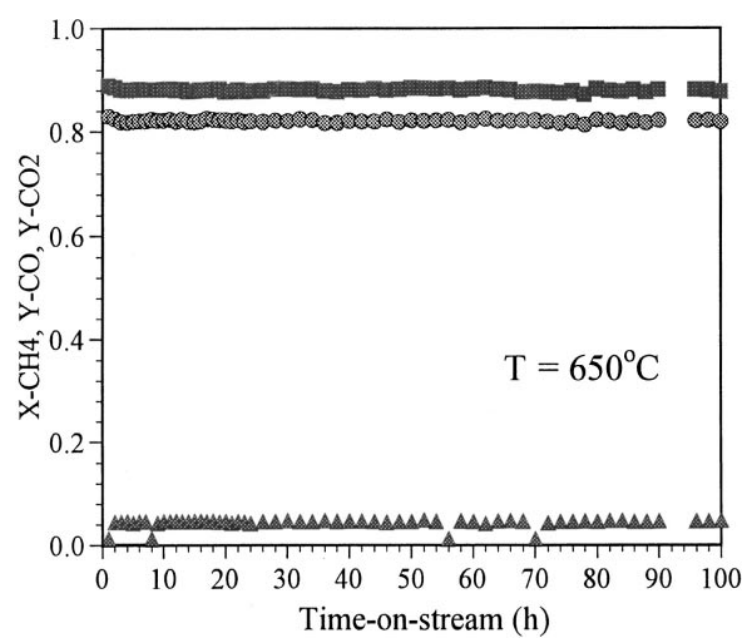

Fig. 10. Activity and stability of 5 at. $\% \mathrm{Ni}-\mathrm{Ce}(\mathrm{La}) \mathrm{O}_{x}$ at $T=650^{\circ} \mathrm{C}$ in a feed gas of $\mathrm{CH}_{4}: \mathrm{O}_{2}=2(\square) \mathrm{X}-\mathrm{CH}_{4},(\otimes) \mathrm{Y}-\mathrm{CO},(\Delta) \mathrm{Y}-\mathrm{CO}_{2}$ $\left(0.18 \mathrm{~g} \mathrm{~s} / \mathrm{cm}^{3}\right.$ (NTP)). 

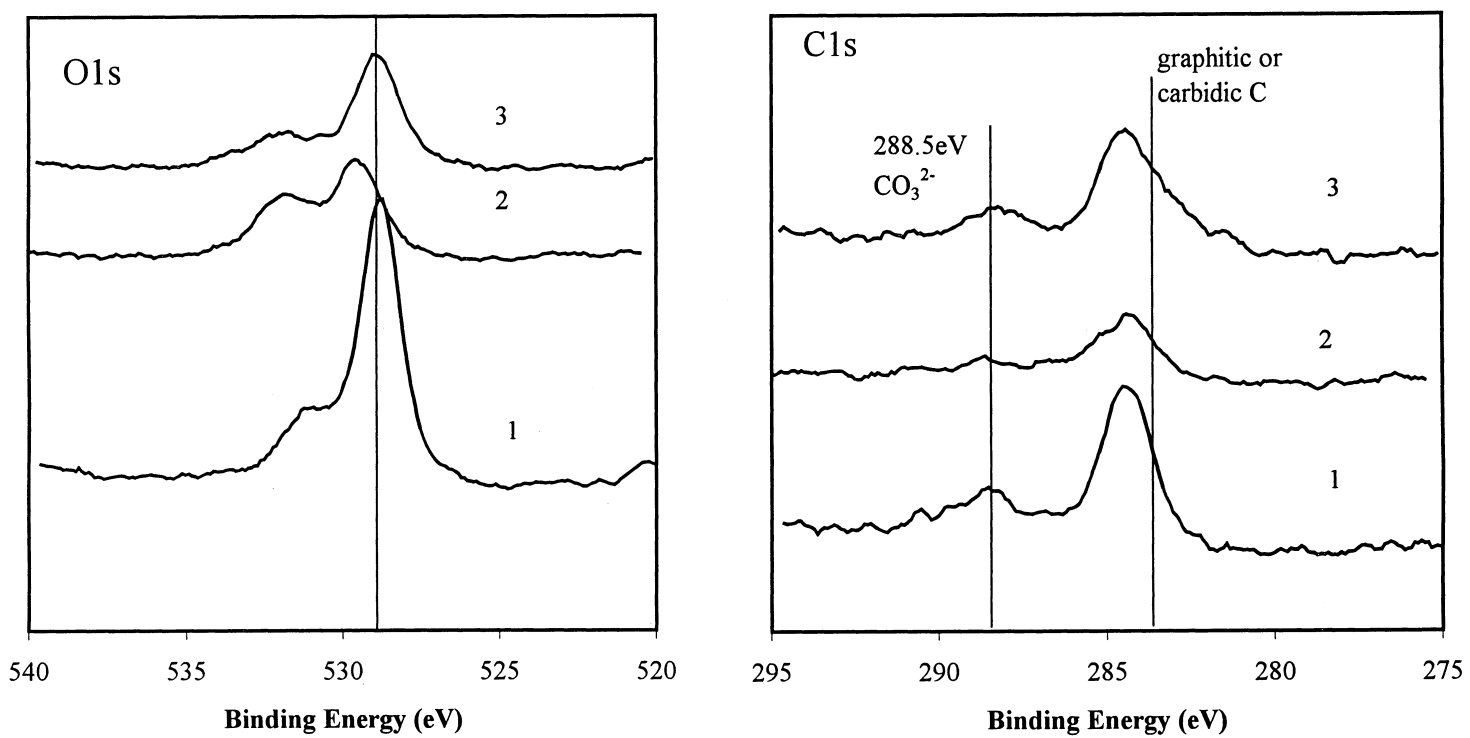

Fig. 11. XPS of (1) as-prepared $5 \% \mathrm{Ni}-\mathrm{CeO}_{2}$, (2) used $5 \% \mathrm{Ni}-\mathrm{Ce}(\mathrm{La}) \mathrm{O}_{x}$ in $1 \% \mathrm{SO}_{2}-2 \% \mathrm{CH}_{4}-\mathrm{He}$, (3) used $5 \% \mathrm{Ni}-\mathrm{Ce}(\mathrm{La}) \mathrm{O}_{x}$ at $650^{\circ} \mathrm{C}$ for $100 \mathrm{~h}$ for POM.
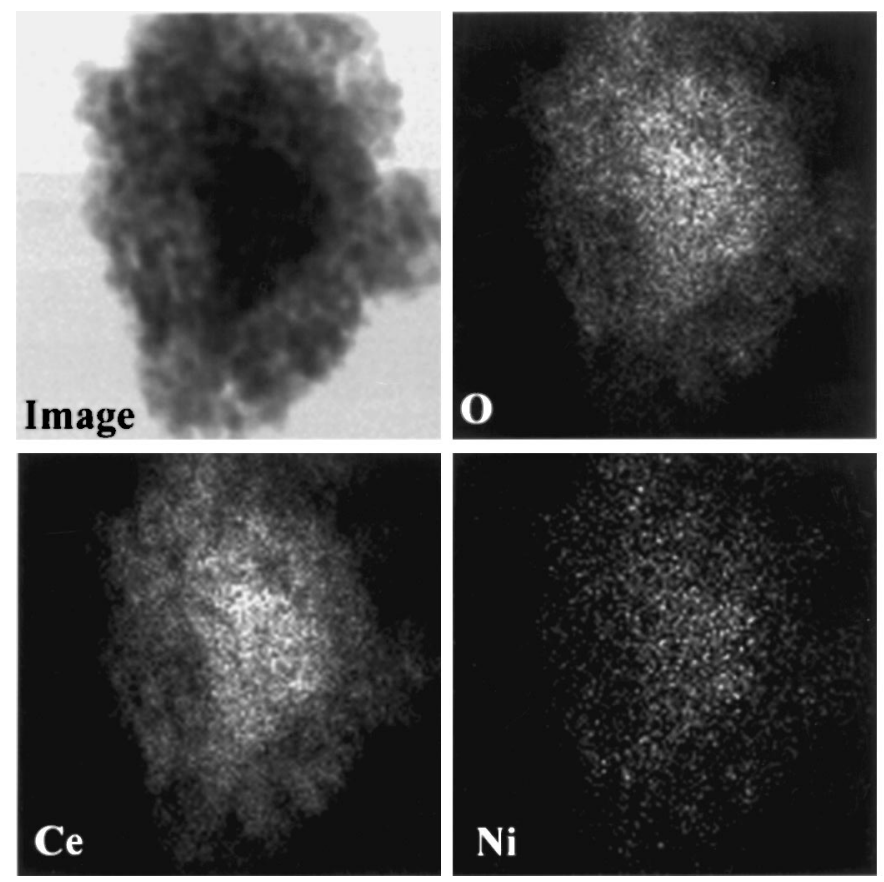

$50 \mathrm{~nm}$

Fig. 12. STEM/EDS elemental mapping of $5 \% \mathrm{Ni}-\mathrm{Ce}(\mathrm{La}) \mathrm{O}_{x}$, as prepared; calcined at $720^{\circ} \mathrm{C}$. 
$(\mathrm{FWHH})=1.8 \mathrm{eV}$ at $284.6 \mathrm{eV}$ and a component at $283.03 \mathrm{eV}$ with $3-8 \%$ of the total carbon signal, close to that on the fresh material. Therefore, XPS found no carbon deposited on the surface of $5 \% \mathrm{Ni}-\mathrm{Ce}(\mathrm{La}) \mathrm{O}_{x}$ after use in fuel-rich conditions. Furthermore, for $5 \% \mathrm{Ni}-\mathrm{Ce}(\mathrm{La}) \mathrm{O}_{x}$ after $100 \mathrm{~h}$-on-stream (see Fig. 10), the weight loss in temperature-programmed oxidation, carried out in a thermogravimetric analyzer over the temperature range of $25-800^{\circ} \mathrm{C}$ was negligible (0.13 wt.\%/100 h) $[38,47]$. Therefore, the low-content $\mathrm{Ni}$-ceria catalyst, 5 at. $\% \mathrm{Ni}-\mathrm{Ce}(\mathrm{La}) \mathrm{O}_{x}$, displays a high resistance to carbon deposition.

The high carbon resistance of 5 at. $\% \mathrm{Ni}-\mathrm{Ce}(\mathrm{La}) \mathrm{O}_{x}$ might be attributed to its high dispersion of nickel and high oxygen mobility. In general, a high degree of metal dispersion may reduce coke formation [56]. Fig. 12 shows the STEM/EDS elemental mapping of the as prepared $5 \% \mathrm{Ni}-\mathrm{Ce}(\mathrm{La}) \mathrm{O}_{x}$. Nickel was highly dispersed in the ceria matrix. Also, XPS analysis found no surface enrichment of nickel in Ni-Ce(La) $\mathrm{O}_{x}$ with a nickel loading up to 10 at.\%, suggesting a homogeneous distribution of nickel throughout ceria. A similar conclusion has been reached for the perovskite-supported $\mathrm{Ni}$ catalysts [57,58] and rare earth metal oxide (La, $\mathrm{Ce}, \mathrm{Y}$ ) modified $\mathrm{Ni} / \mathrm{Al}_{2} \mathrm{O}_{3}$ catalysts [59-61]. The enhanced resistance to carbon deposition was attributed to improved dispersion of the active component nickel.

The high oxygen storage capacity and oxygen ion mobility of ceria may also contribute to the high carbon resistance of 5 at. $\% \mathrm{Ni}-\mathrm{Ce}(\mathrm{La}) \mathrm{O}_{x}$. A high rate of oxygen supply to the nickel interface may speed up the surface oxidation of carbon species, thus inhibiting the deposition of carbon on the catalyst surface. A similar reason may be applied to perovskite-supported nickel $[57,58]$ as perovskite-type oxides are well known for their high oxygen mobility. For the modified Ni/ $\mathrm{Al}_{2} \mathrm{O}_{3}$ catalyst [59-61], addition of cerium can modify the surface oxygen properties of aluminum oxide, thus, providing a higher rate of surface oxidation of carbon species and improving this material's resistance to carbon deposition.

\section{Conclusions}

$\mathrm{Cu}$ - or Ni-modified ceria are active and selective catalysts for $\mathrm{SO}_{2}$ reduction by $\mathrm{CO}$ to elemental sulfur under a variety of operating conditions. The addition of 5 at.\% ( $\sim 2.5 \mathrm{wt} . \%)$ copper or nickel significantly improves the low-temperature reactivity of ceria and its resistance to water vapor poisoning up to very high levels of water $(>40 \%)$. Such difference is believed to result from available $\mathrm{CO}$ adsorption sites on the metal that are not poisoned by $\mathrm{H}_{2} \mathrm{O}$. The metal-ceria catalysts also show high activity for low-temperature WGS reaction. Both the $\mathrm{CO}-\mathrm{SO}_{2}$ and $\mathrm{CO}-\mathrm{H}_{2} \mathrm{O}$ reactions are favored over $\mathrm{Ni}$ - or $\mathrm{Cu}$-containing ceria due to the enhanced redox activity of ceria in the presence of the metal.

The combined reduction of $\mathrm{SO}_{2}$ and $\mathrm{NO}$ by $\mathrm{CO}$ was studied in this work over the ceria-based catalysts. In dilute gas mixtures containing $0.1-1.0 \mathrm{~mol}_{2} \mathrm{SO}_{2}$ and $\mathrm{NO}$, stoichiometric amount of $\mathrm{CO}$ and in the presence of $40 \% \mathrm{H}_{2} \mathrm{O}$, the $\mathrm{NO}$ presence in the feed gas enhances both the $\mathrm{SO}_{2}$ conversion and the elemental sulfur yield. The $\mathrm{Ni}-\mathrm{CeO}_{x}$ appears to be the most active catalyst for the combined reduction of $\mathrm{SO}_{2}$ and $\mathrm{NO}$ by $\mathrm{CO}$. This is a very useful result for $\mathrm{NO}_{x}$ reduction because most NO reduction catalysts are susceptible to sulfur poisoning.

Ceria-based materials are also active for $\mathrm{SO}_{2}$ reduction by methane to elemental sulfur at temperatures higher than $550^{\circ} \mathrm{C}$. The addition of $\mathrm{Cu}$ or $\mathrm{Ni}$ into ceria has different effect on the sulfur selectivity of the catalyst under fuel-rich conditions. The $\mathrm{Cu}$-ceria system is a complete oxidation catalyst to a much higher temperature than $\mathrm{Ni}$-ceria. Over $\mathrm{Ni}-\mathrm{CeO}_{2}$, dissociation of methane begins at $<550^{\circ} \mathrm{C}$, and side reactions favor $\mathrm{H}_{2} \mathrm{~S}$ production over elemental sulfur. However, the 5 at. $\% \mathrm{Ni}-\mathrm{Ce}(\mathrm{La}) \mathrm{O}_{x}$ catalyst showed a remarkable resistance to carbon deposition, both in the $\mathrm{SO}_{2}$-methane reaction as well as in partial oxidation of methane by $\mathrm{O}_{2}$ to synthesis gas with a $2: 1 \mathrm{H}_{2}$ :CO ratio. This is attributed to high dispersion of nickel and the fast rate of oxygen supply from ceria to the nickel interface.

\section{Acknowledgements}

We gratefully acknowledge the financial support of this work by Reaction Engineering International under contract with NASA, grant no. NAS2-97018, and the US DOE under contract no. DE-AC-95PC95252 to Arthur D. Little, Inc. /subcontr. to Tufts University. 


\section{References}

[1] J.H. Seinfeld, Atmospheric Chemistry and Physics of Air Pollution, Wiley, New York, 1986.

[2] G.M. Masters, Introduction to Environmental Engineering and Science, Chapter 7, 2nd Edition, Prentice-Hall, Eglewood Cliffs, 1996.

[3] J.B. Rinckhoff, J.B. Pfeiffer (Eds.), Sulfur Removal and Recovery from Industrial Processes, Adv. in Chem. Series No. 139, American Chemical Society, Washington, DC, 1975.

[4] R. Lepsoe, Ind. Eng. Chem. 30 (1938) 92.

[5] R. Lepsoe, Ind. Eng. Chem. 32 (1940) 910.

[6] S.E. Khalafalla, E.F. Foester, L.A. Haas, Ind. Eng. Chem. Prod. Res. Dev. 10 (1971) 133.

[7] D.B. Hibbert, A.C.C. Tseung, J. Chem. Soc., Faraday Trans. 74 (1978) 1981.

[8] L. Bajars et al., US. Patent 3978200 (1976).

[9] J.G.I. Bazes, L.S. Caretto, K. Nobe, Ind. Eng. Chem. Prod. Res. Dev. 14 (1975) 264.

[10] D.B. Hibbert, A.C.C. Tseung, J. Chem. Technol. Biotech. 29 (1979) 713.

[11] J.M. Whelan, US Patent 4081519 (1977).

[12] D.B. Hibbert, R.H. Campbell, Appl. Catal. 41 (1988) 273.

[13] D.B. Hibbert, R.H. Campbell, Appl. Catal. 41 (1988) 289.

[14] J.A. Baglio, Ind. Eng. Chem. Prod. Res. Dev. 21 (1982) 38.

[15] J. Ma, M. Fang, N.T. Lau, J. Catal. 158 (1996) 251.

[16] J. Ma, M. Fang, N.T. Lau, J. Catal. 163 (1996) 271.

[17] J. Ma, et al., US Patent 5853684 (1999).

[18] H. Kim, D.W. Park, H.C. Woo, J.S. Chung, Appl. Catal. B 19 (1998) 233.

[19] W. Liu, A.F. Sarofim, M. Flytzani-Stephanopoulos, Appl. Catal. B. 4 (1994) 167.

[20] M. Flytzani-Stephanopoulos, W. Liu, U.S. Patent No. 5384301 (1995).

[21] W. Liu, Sc.D. Thesis, Massachusetts Institute of Technology, 1995.

[22] A. Tschoepe, W. Liu, M. Flytzani-Stephanopoulos, J.J. Ying, J. Catal. 157 (1995) 42.

[23] W. Liu, C. Wadia, M. Flytzani-Stephanopoulos, Catal. Today 28 (1996) 391.

[24] Y. Li, M.S. thesis, Department of Chemical Engineering, Tufts University, 1998.

[25] J.J. Helstrom, G.A. Atwood, Ind. Eng. Chem., Process Des. Dev. 17 (1978) 114.

[26] J. Sarlis, D. Berk, Ind. Eng. Chem. Res. 27 (1988) 1951.

[27] M.M. Akhmedov, G.B. Shakhtakhtinskii, A.I. Agaev, S.S. Gezalov, Zhurnal Prikladnoi Khimii 59 (1986) 504.

[28] E.M. Nekrich, A.N. Kontsevaya, G.F. Ganzha, J. Appl. Chem. U.S.S.R. 51 (1978) 517.

[29] D.J. Mulligan, D. Berk, Ind. Eng. Chem. Res. 28 (1989) 926.

[30] D.J. Mulligan, D. Berk, Ind. Eng. Chem. Res. 31 (1992) 119.

[31] J. Sarlis, D. Berk, Chem. Eng. Comm. 140 (1996) 73.

[32] T.S. Wiltowski, K. Sangster, W.S. O'Brien, J. Chem. Technol. Biotech. 7 (1996) 204.
[33] J.J. Yu, Q. Yu, Y. Jin, S.G. Chang, Ind. Eng. Chem. Res. 36 (1997) 2128.

[34] A. Trovarelli, Catal. Rev.-Sci. Eng. 38 (4) (1996) 439.

[35] T. Zhu, Lj. Kundakovic, M. Flytzani-Stephanopoulos, Catal. Today 50 (1999) 381.

[36] T. Zhu, A. Dreher, M. Flytzani-Stephanopoulos, Appl. Catal. B 21 (1999) 103.

[37] T. Zhu, M. Flytzani-Stephanopoulos, ACS Volume on Green Eng. Process., in press.

[38] T. Zhu, M. Flytzani-Stephanopoulos, Appl. Catal. A, in press.

[39] Lj. Kundakovic, M. Flytzani-Stephanopoulos, Appl. Catal. A 171 (1998) 13.

[40] Lj. Kundakovic, Ph.D. Thesis, Tufts University, 1998.

[41] C. Li, Y. Sakata, K. Domen, K. Maruya, T. Onishi, J. Am. Chem. Soc. 3 (1989) 7683.

[42] Y. Li, Q. Fu, M. Flytzani-Stephanopoulos, Appl. Catal. B Env. 27 (2000) 179-191.

[43] H.C. Yao, Y.F. Yao, J. Catal. 86 (1984) 254.

[44] J.A. Rodriguez, T. Jirsak, A. Freitag, J.C. Hanson, J.Z. Larese, S. Chaturvedi, Catal. Lett. 62 (1999) 113.

[45] K.C. Taylor, Catal. Rev. Sci. Eng. 35 (1993) 457.

[46] M. Flytzani-Stephanopoulos, Z. Li, Kinetics of sulfidation reactions between $\mathrm{H}_{2} \mathrm{~S}$ and bulk oxide sorbents, in: A.A. Atimtay, D.P. Harrison (Ed.), Proceedings of the NATO ASI on Desulfurization of Hot Coal Gas, Vol. 42, Springer, Berlin, 1998.

[47] T. Zhu, Ph.D. Thesis, Department of Chemical Engineering, Tufts University, 2000.

[48] W. Liu, M. Flytzani-Stephanopoulos, J. Catal. 153 (1995) 304.

[49] E. Zamar, A. Trovarelli, C. de Leitenburg, G. Dolcetti, J. Chem. Soc., Chem. Commum. (1995) 965.

[50] K. Otsuka, T. Ushiyama, I. Yamanaka, Chem. Lett. (1993) 1517.

[51] K. Otsuka, E. Sunada, T. Ushiyama, I. Yamanaka, Stud. Surf. Sci. Catal. 107 (1997) 531.

[52] K. Otsuka, Y. Wang, E. Sunada, I. Yamanaka, J. Catal. 175 (1998) 152.

[53] S.C. Tsang, J.B. Claridge, M.L.H. Green, Catal. Today 23 (1995) 3.

[54] J.B. Claridge, M.L.H. Green, S.C. Tsang, A.P.E. York, A.T. Aschcroft, P.D. Battle, Catal. Lett. 22 (1993) 299.

[55] Handbook of X-ray Photoelectron Spectroscopy, PerkinElmer, Physical Electronics Division, 1978.

[56] C.H. Bartholomew, Catal. Rev.-Sci. Eng. 24 (1982) 67.

[57] R. Shiozaki, A.G. Andersen, T. Hayakawa, S. Hamakawa, K. Suzuki, M. Shumizu, K. Takehira, J. Chem. Soc., Faraday Trans. 93 (1997) 3235.

[58] T. Hayakawa, H. Harihara, A.G. Andersen, K. Suzuki, H. Yasuda, T. Tsunoda, S. Hamakawa, A.P.E. York, Y.S. Yoon, M. Shimizu, K. Takehira, Appl. Catal. A 149 (1997) 391.

[59] Q. Miao, G. Xing, S. Sheng, W. Cui, L. Xu, X. Guo, Appl. Catal. A 154 (1997) 17.

[60] L. Cao, Y. Chen, W. Li, Stud. Surf. Sci. Catal. 107 (1997) 467.

[61] W. Chu, Q. Yan, X. Liu, Z. Yu, G. Xiong, Stud. Surf. Sci. Catal. 119 (1998) 849. 